\title{
ISCHEMIC STROKE IN CHILDREN
}

\section{A study of the associated alterations}

\author{
Josiane Ranzan', Newra Tellechea Rotta²
}

\begin{abstract}
Arterial ischemic stroke (AIS) in children is a relatively rare disease, not yet clearly understood and with a multifactored etiology. It can cause a severe impact on the child and be the first manifestation of a systemic disease. Delayed diagnosis is still common and research on the subject in our field practically does not exist. Prothrombotic disorders have been described as important causative factors of the ischemic event in children. Forty-six patients from zero to 18 years of age diagnosed with AIS were studied in the period between March 2002 and September 2003. Laboratory tests were realised including coagulation proteins and echocardiogram. AIS of the newborn occurred in $37 \%$ of the cases. Focal seizures and hemiparesis were the most frequent symptoms; $40 \%$ of the patients presented prior pathologies. Abnormalities of the $S$ and C proteins occurred in $22 \%$ and $17 \%$. Associated alterations, particularly those that generate a hypercoagulability state, indicate more than one risk factor for this disease in childhood.
\end{abstract}

KEY WORDS: cerebrovascular disease, coagulation disorders, children.

\begin{abstract}
Acidente vascular cerebral isquêmico na infância: estudo das alterações associadas
RESUMO - Acidente vascular cerebral Isquêmico (AVCI) na infância é relativamente raro, de conhecimento ainda obscuro, e com etiologia multifatorial. Pode causar grave impacto na criança e ser a primeira manifestação de doença sistêmica. O subdiagnóstico ainda é comum e são praticamente inexistentes as pesquisas sobre o assunto no nosso meio. Desordens protrombóticas têm sido descritas como importantes fatores causais do evento isquêmico na infância. Foram estudados 46 pacientes de zero a 18 anos, com diagnóstico de $\mathrm{AVCl}$, no período de março/2002 a setembro/2003. Exames laboratoriais, incluindo proteínas de coagulação e ecocardiograma foram realizados. AVCI neonatal ocorreu em 35\% dos casos. Crise focal e hemiparesia foram os sintomas iniciais mais freqüentes; $40 \%$ dos casos apresentaram patologia prévia. Anormalidades nas proteínas S e C ocorreram em $22 \%$ e $17 \%$ da amostra. Alterações associadas, principalmente as que geram um estado hipercoagulável, indicam que mais de um fator de risco pode causar essa doença na infância.
\end{abstract}

PALAVRAS-CHAVE: doença cerebrovascular, desordens da coagulação, infância.

In children, arterial ischemic stroke (AIS) has been considered a rare event with pathophysiology, evolution and treatment still obscure. However, in recent decades the frequency of such strokes seems to be increasing, and this change may be due to two factors: the improvement in technical quality and easier access to radiological testing, and the reduction of mortality plus the increase in survival of patients who have pathologies potentially responsible for, or associated with, strokes. The rate of incidence has increased from 1.2 to 2.7 per 100000 children/year ${ }^{1,2}$.

The typical clinical presentation of AIS is a prolonged focal neurologic deficit, of acute onset, as for example, hemiparesis ${ }^{3}$. Seizures also may be the first manifestation ${ }^{4}$ especially in the newborn ${ }^{1,3}$. Sometimes, the cause of AIS is easily defined especially when the patient has a basic disease such as sickle cell disease or congenital heart disease. From this point on, however, the scope for investigation of the risk factors in each individual case may be very limited ${ }^{5}$. The majority of investigators have stressed the importance of a complete investigation in a considerable portion of the cases excluding those where the cause is very obvious. Prothrombotic disorders have received special attention in recent researches in view of the fact that thromboembolic events are the major factors caus-

\footnotetext{
${ }^{1}$ Medical doctor in pediatric neurology, Masters Degree in the postgraduate Pediatric Program of the Federal University of Rio Grande do Sul, Porto Alegre RS, Brazil; ${ }^{2}$ Professor of Pediatric Neurology, The Federal University of Rio Grande do Sul, and Chief of the Pediatric Neurological Unit of the Hospital das Clinicas, Porto Alegre RS, Brazil.
}

Received 24 November 2003, received in final form 1 March 2004. Accepted 2 April 2004. 
ing AIS in children ${ }^{6,7}$. Examples of coagulation defects are: $S$ and $C$ protein deficiencies, antithrombin deficiencies, and the presence of resistance to the activated $C$ protein and plasminogen deficiencies $^{1}$. The anticardiolipin antibodies are also considered important risk factors in stroke genesis, because they also contribute to the prototrombothic state in children.

The present study proposes to identify alterations associated with AIS in the childhood in patients of the Hospital de Clínicas de Porto Alegre (HCPA) and specifically, to establish the ethiology, describe the therapeutic treatment and identify abnormalities in the coagulation proteins of the research group.

\section{METHOD}

The present is an investigative study of a series of cases derived from a sample of patients of zero to eighteen years old diagnosed as having AIS attended at the outpatients clinic for Cerebrovascular Disease for children the HCPA in the period between March 2002 and September 2003. The older cases were recovered from the files by use of the International Disease Code while the new cases came from the outpatient clinics, from hospitalised patients or those treated in the emergency departments of the HCPA. Only cases confirmed by clinical evaluation and radiographic tests were accepted for the study. The criterion for exclusion was the disagreement of those responsible for the patient to sign the Information and Consent forms. The AIS in the neonatal period may include the ischemic event that ocurred intrautero.

The variables in the study were: sex, age at the onset of AIS and at the date included in the research, death, complications before and during birth, the AIS symptoms manifested, the presence of infection, previous associated pathologies, findings in neuroimaging, neurological examination results, laboratory tests (hemogram, antinuclear antibodies, hemoglobin electrophoresis, antiphospholipid antibodies, protein C, protein S, antithrombin, activated protein $C$ resistance, lipidic profile), echocardiography, use of medication, and the evolution of the patient. The results were analysed using the SPSS, version 10.0 software packet.

The Scientific Commission and the HCPA's Commission for Ethics in Health approved the research.

\section{RESULTS}

Forty-nine patients suspected of AIS were evaluated during the study period. Three cases were excluded because the diagnosis was not confirmed. One showed normal brain computed tomography (CT), one with hemorrhagic stroke and one with a neurodegenerative disease. Of the remaining 46 patients with AIS, 17 had AIS in the neonatal period. Twelve newborn had the AIS diagnosticated in the first days of life and, in the other five the diagnosis was made months later throught a clinical picture of epilepsy and/or hemiparesis. One pacient was pre-term. Other 29 patients contracted the disease at various ages between one month and 216 months (18 years). In average, the sample group members contracted AIS at the age of 32 months. As regards sex, $52 \%$ of the patients are female and as regards the side effected, a slight predominance $(48 \%)$ of the left to be the affected side was observed and $17 \%$ had bilateral lesions. Two cases, of sickle cell disease, had a reincidence of AIS.The most frequent initial manifestations were: focal seizures in $43.5 \%$, and when the newborn group only was considered, 50\%; hemiparesis occurred in 41,3\% and other symptoms reported were generalised crises, cyanoses, coma, vomiting, dismetry, anisocoria and aphasia (Table 1).

Antenatal and perinatal complications were present in $25 \%$ of the patients and were characterised by alterations: maternal (early placenta, preeclampsia, toxoplasmosis, premature birth labour) and fetal (intrautero seizures, neonatal asphyxia, severe fetal suffering and prematurity). Such conditions were significantly more frequently associated to AIS in the newborn than in the other age groups. $(p<0.001)$. Prior disease occurred in $40 \%$ of the sample. Of these $22 \%$ are carriers of genetic pathology, two with Down's syndrome; one with chromosome deletion 18 (q21.3) and another with a split palate and facial dimorphism (Pierre Robin's syndrome). Other associated diseases were four cases of sickle cell disease, three cancer cases (osteosarcoma, acute lymphatic leukemia); two cases of

Table 1. Clinical manifestation of arterial ischemic stroke.

\begin{tabular}{lcc}
\hline Symptom/Sign & $\mathrm{n}$ & $\%$ \\
\hline Focal seizure & 20 & 43.5 \\
Hemiparesis & 19 & 41.3 \\
Generalized seizure & 5 & 10.9 \\
Cyanoses & 2 & 4.3 \\
Coma & 3 & 6.5 \\
Vomiting & 3 & 6.5 \\
Dismetry & 1 & 2.2 \\
Anisocoria & 1 & 2.2 \\
Aphasia & 2 & 4.3 \\
\hline
\end{tabular}

*12 patients presented more than one clinical manifestation. 
congenital heart disease (Fallot's tetralogy and aorta coarctation); two cases of acquired immune deficiency syndrome (AIDS); and one case each of diabetes mellitus, hyperthyroidism, kidney disease and epilepsy. AIS in the newborn presented significantly less associated pathologies $(p=0.01)$ (Table 2 ). In the two cases of congenital heart disease, AIS occurred in the postoperative period following surgery for the correction of a cardiac defect and was secondary to the surgical procedure. Other cardiac alterations corresponded to echocardiographic findings such as three cases of patent foramen ovale and one case each of mitral insufficiency, mixoma of the left atrium, inter-atrial communication, and thickening of the front tissue of the mitral valve.

The vascular territory principally affected was that of the middle cerebral artery $(71.7 \%)$; followed by the posterior cerebral artery $(13 \%)$; anterior cerebral $(6.5 \%)$; internal carotid $(4.3 \%)$; basi$\operatorname{lar}(2.2 \%)$ and the superior cerebellar artery $(2.2 \%)$. In the majority of cases the diagnosis was made by CT (63\%) followed by magnetic resonance $(9 \%)$ and angioresonance (9\%). Conventional arteriography was not used on any patient. In six cases the bilateral vascular was compromised and in one of these the alterations were of circulation anterior right and posterior left (Figs 1,2,3). The cerebral vascular event was associated with infections, of both viral and bacteriological types, in $31 \%$ of the

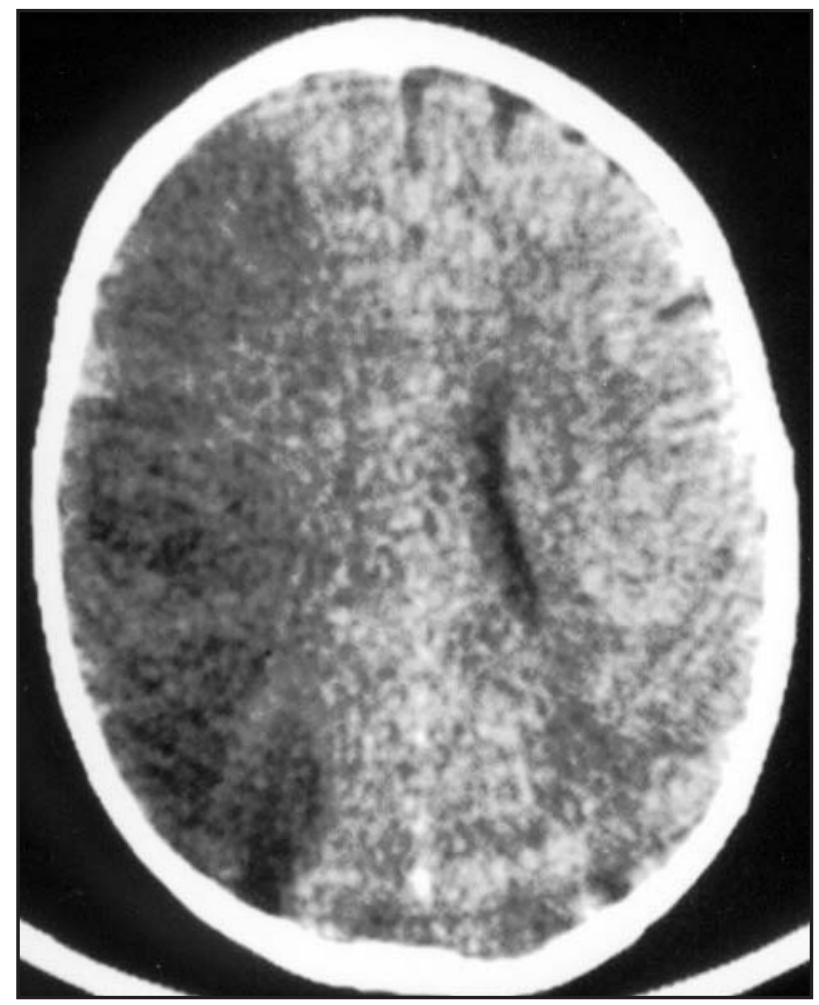

Fig 1. CT- large-vessel arterial infarct in the right middle cerebral artery territory.

cases. Sepsis was the most prevalent infection and occurred in 7 cases. Pneumonia, otitis media, sinusitis, viral gastroenteritis, necrotizing enterocolitis, herpetic encephalitis, tuberculous meningitis, urina-

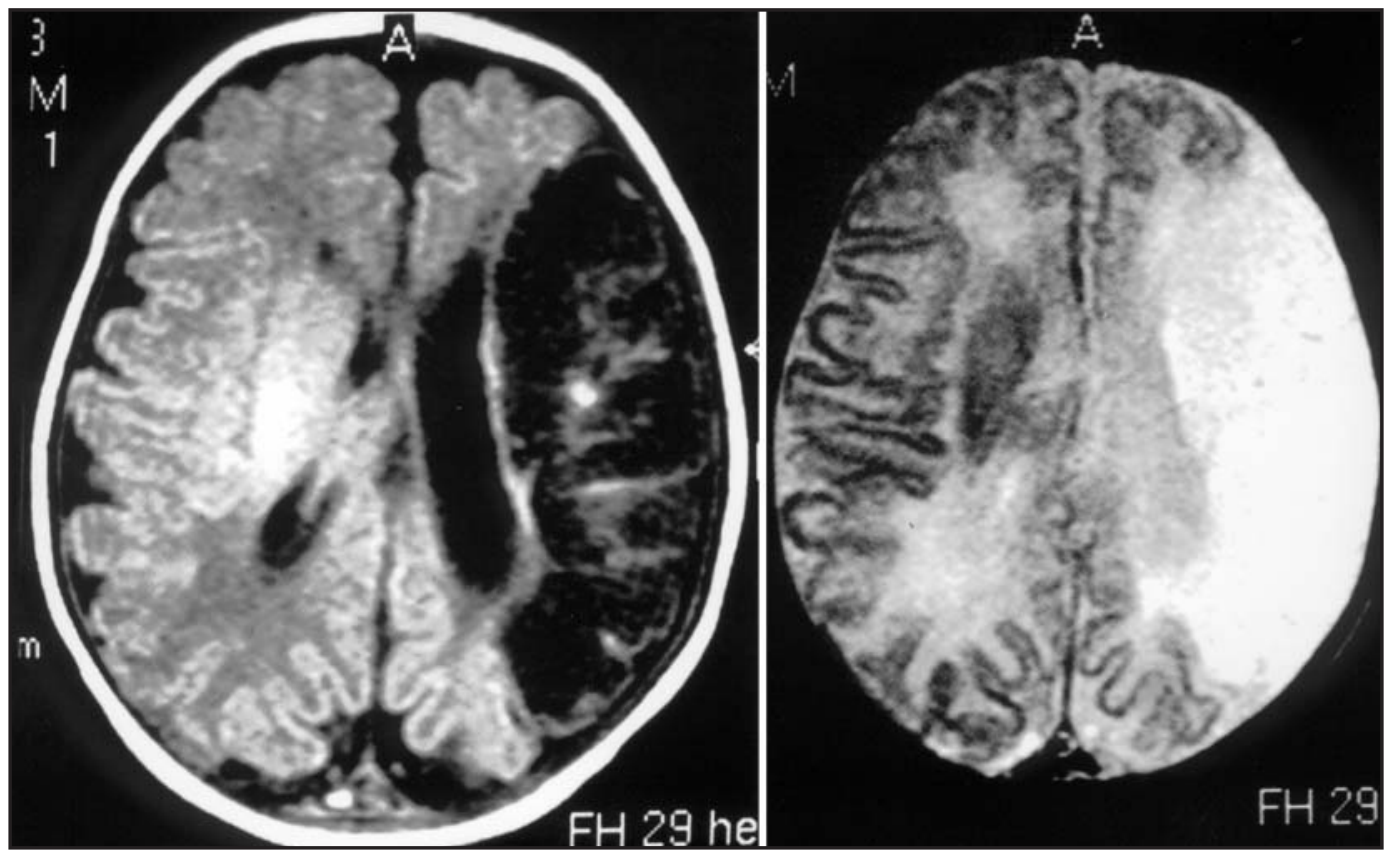

Fig 2. T1 and T2-weighted magnetic resonance demonstrating left infarct in the middle cerebral artery territory. 


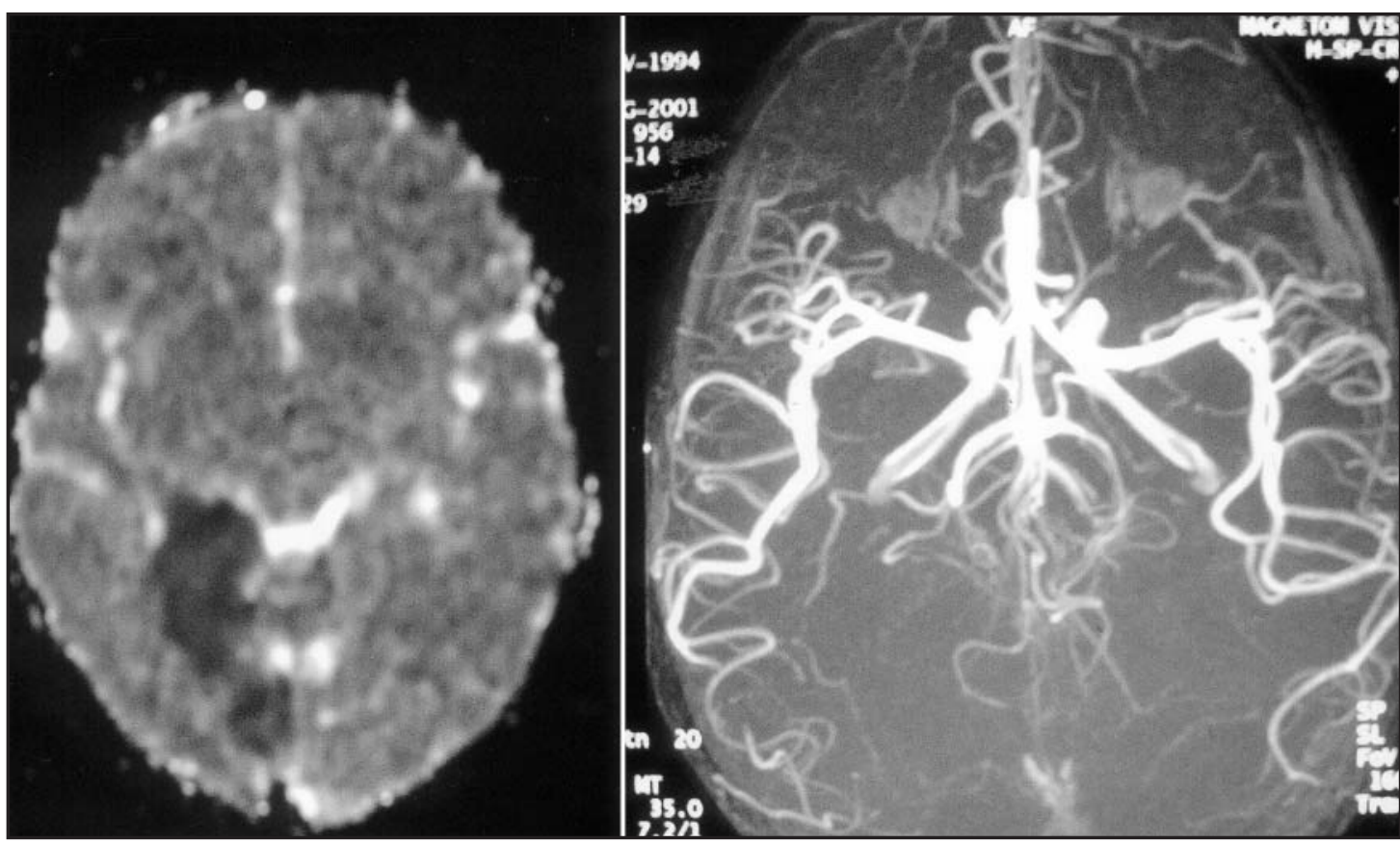

Fig 3. Magnetic resonance and angioresonance demonstrating a bilateral infarct in the posterior cerebral arteries territories.

Table 2. Associated alterations in the arterial ischemic stroke according age.

\begin{tabular}{|c|c|c|c|c|c|}
\hline \multirow{3}{*}{ Characteristics } & \multicolumn{2}{|c|}{ Neonate } & \multicolumn{2}{|c|}{$>28$ days } & \multirow{3}{*}{$\mathrm{p}$} \\
\hline & $\mathrm{n}$ & $(\%)$ & $\mathrm{n}$ & $(\%)$ & \\
\hline & 17 & (37) & 29 & (63) & \\
\hline Prior disease & 1 & (5.8) & 17 & (58) & 0.01 \\
\hline Down's syndrome & 0 & $(0)$ & 2 & (6.8) & \\
\hline Del. crh. 18 & 0 & (0) & 1 & (3.4) & \\
\hline Split palate & 1 & (5.8) & 0 & (0) & \\
\hline Sickle cell anemia & 0 & $(0)$ & 4 & $(13.7)$ & \\
\hline Cancer & 0 & (0) & 2 & (6.8) & \\
\hline Congenital heart disease & 0 & $(0)$ & 2 & $(6.8)$ & \\
\hline AIDS & 0 & $(0)$ & 2 & (6.8) & \\
\hline Others & 0 & (0) & 4 & $(13.7)$ & \\
\hline Peri/prenatal complications & 9 & (52.9) & 1 & (3.8) & $<0,001$ \\
\hline Echocardiographic findings & 2 & $(12.5)$ & 6 & $(23.1)$ & NS \\
\hline Infection & 3 & (17.6) & 11 & (40.7) & NS \\
\hline
\end{tabular}

ry infection and inespecified viral condition were the other infections reported. Patients with more than 28 days of life had more infections but there was no statistical significance (OR=3.2; $\mathrm{p}=0.184$ ) (Table 2).

Protein $\mathrm{C}$ deficiency occurred in $17.1 \%$ of the cases, and of the $S$ protein in $22.5 \%$, the presence of activated protein $C$ resistance was observed in $12.9 \%$ and of antithrombin deficiency in $5.4 \%$ of the tested patients (Table 3 ). Two patients had transitory proteins deficiences which normalised in the follow-up tests. Five patients presented two combined deficiencies of the natural coagulation 
Table 3. Alterations in prothrombotic testing.

\begin{tabular}{lccc}
\hline Prothrombotic test & $\begin{array}{c}\mathrm{n} \text { of patients } \\
\text { tested }\end{array}$ & $\begin{array}{c}\mathrm{n}(\%) \text { of patients with } \\
\text { abnormal results }\end{array}$ \\
\hline Protein C & 35 & 6 & $(17.1)$ \\
Protein S & 40 & 9 & $(22.5)$ \\
Antithrombin & 37 & 2 & $(5.4)$ \\
Activated protein C resistance & 31 & 4 & $(12.9)$ \\
Anticardiolipin antibody & 39 & 5 & $(12.8)$ \\
Total & 41 & $17 \quad(41.4)$ \\
\hline
\end{tabular}

*6 of 41 patients had more than one alteration.

Table 4. Outcome during following.

\begin{tabular}{lcc}
\hline Characteristics & $\mathrm{n}$ & $\%$ \\
\hline Epilepsy & 21 & 49 \\
Retarded development & 15 & 35 \\
Motor impairment & 37 & 86 \\
Visual alterations & 3 & 7 \\
Speech alterations & 3 & 7 \\
\hline
\end{tabular}

inhibitors. The anticardiolipin antibodies were reactive in $12.8 \%$ of the tested patients with the IgG fraction being positive in 3 cases and the IgM fraction positive in 2 cases. Considering the lipidic profile, the commonest alteration found was an increase in total cholesterol in $22 \%$ followed by an increase in triglycerides in $12.2 \%$ and LDL alteration in $4 \%$ of the examinations realised. No patient showed alteration of the HDL fraction.

In the neurological examination the most frequent finding was hemiparesis which was present in $76 \%$ of the patients, $57 \%$ on the right side and $43 \%$ on the left. The examination was symmetrical with normal force in $8.7 \%$ of the cases; paresis of the lower left member $(6.5 \%)$, paresis of the right upper member (4.3\%) and tetraparesis/aphasia $(4.3 \%)$ were the other findings. There were no differences between the age of the patients and the alterations of the physical examination.

The average case follow-up time was 43.5 months (median 31 months) and it was possible to detect after-effects such as epilepsy (49\%), retarded development (35\%), motor deficiencies $(86 \%)$, visual alterations $(7 \%)$ and speech alterations $(7 \%)$ (Table 4). Up to the present moment, only one patient had no after-effects and $58 \%$ presented more than one disease after the AIS. It was observed that
Table 5. Drugs used during outcome.

\begin{tabular}{lcc}
\hline Drugs & $\mathrm{n}$ & $\%$ \\
\hline Antiepileptics & 27 & 58.6 \\
Aspirin & 12 & 26.0 \\
Oral anticoagulant & 1 & 2.1 \\
Antipsychotic & 1 & 2.1 \\
None & 14 & 30.0 \\
\hline *10 patients used more than one drug. & &
\end{tabular}

there is moderate degree of association between the number of associated alterations observed in the patients and the number of after-effects they experienced. ( $p=0.009 ; r=0.39$ ). It appears that the coagulation disturbances, alteration of the $C$ and $S$ proteins, resistance to the activated $\mathrm{C}$ protein and antithrombin, are less associated to the motor sequelae, and may even be protective factors for motor alterations in AIS bearers although this does not have statistical significance $(O R=0.21 ; p=0.161)$. The analysis showed a tendency toward significance in the difference between AIS in the anterior and posterior territories in relation to the motor sequelae. These are much smaller in the posterior circulation vessels $(p=0.067)$. Furthermore, in relation to circulation, an important association was discovered between AIS of the posterior territory and visual alterations as an after-effect (OR $=11.4$; $p=0.084)$. There was no association between the presence of coagulation disturbances and other types of after-effects.

Antiepileptic drugs were the most frequently used $(58,6 \%)$ with aspirin in second place $(26 \%)$. One patient used an oral anticoagulant and aspirin and another used an antipsychotic drug as well as anticonvulsive medicament and aspirin. Fourteen patients did not receive any drug treatment (Table 5). 
There were two deaths: one patient who had sickle cell disease as a result of an extensive stroke lesion which caused a diffused a cerebral edema and herniation, and the other, with leukemia as consequence of the base disease.

\section{DISCUSSION}

The study population $(n=46)$ was greater than had been estimated $(n=30)$ on the basis of the number of patients diagnosed annually, indicating that the search for patients with of AIS could have as a consequence the inclusion of underdiagnosed cases as this disease is relatively rare and little known. Golomb et al studied 22 children with perinatal AIS whose criteria for inclusion was normal newborn history, hemiparesis, and/or seizures after the second month alive and alteration of the neuroimage results compatible with an old stroke ${ }^{8}$. Many studies have been realised with newborn who had AIS which show the prevalence of this age group ${ }^{8-10}$. This fact agrees with our research in which more than a third in which of the population has perinatal AIS. Other researches show that AIS occurs in this age period in between 20 and $50 \%$ of the entire sample ${ }^{3,6,11}$. In this study the average age at which AIS occurred in the post birth period was 2 years and 6 months which disagrees with other studies in which the occurrence age was at 5 years ${ }^{12,13}$ and this suggests that, as time goes on, this pathology is being diagnosed earlier.

The female sex was most affected in the present study with $52 \%$ of the cases contrary to the great majority of the other studies where the male sex represents between 50 and $60 \%$ of the cases $^{7,11,12,14-17}$. Perhaps this is due to the association of the male sex with arterial trauma dissection as a basic cause of $\mathrm{AIS}^{18}$, which did not occur in this study.

In our study seizures was the most prevalent symptom, principally the focal crisis $(55 \%)$ followed by hemiparesis $(42 \%)$ which suggests that the differences are related to the ages of inclusion in the research, because when studied from newborn to adolescence, as in this present study, the differences between the prevalence of the most important initial symptoms tends to reduce. That the left side is the most affected agrees with the literature ${ }^{8,10,14}$. Ganesan et al. found that hemiparesis was the most prevalent symptom in the initial phase $(83 \%)$ followed by seizures $(33 \%)$ in children with 3 months or more ${ }^{13}$. Bonduel et al. also in a study with infants, reported that hemipa- resis and seizures were the most frequent initial symptoms ${ }^{7}$. In a study confined to full-term newborn, Gunther et al. reported that seizures were part of the initial clinical presentation in $77 \%$ of the cases and the focal crises were the most common?.

Peri or prenatal complication is considered one of the risk factors for AIS which was confirmed in our study because one quarter of the cases presented some kind of alteration in the maternal-fetal history especially in the AIS newborn which agrees with Golomb et al. who detected $81 \%$ of consistent complications in the gestational and obstretical history of 22 patients 8 . It is known that any injury to the placentary circulation can evolve into an abnormality in the cerebral circulation of the fetus or the newborn, resulting in ischemia ${ }^{19}$.

When the patient has a prior disease before the cerebral stroke occurs, the associated cause is attributed to the child's earlier condition especially if the base pathology has AIS as a complication. On the other hand, the AIS could be the first manifestation of a serious disease such as AIDS and this actually occurred in one of our patients and is also found in the literature ${ }^{20}$. In the present research, $40 \%$ of the patients presented earlier pathologies of which the majority had a genetic origin or sickle cell disease - the latter being one of the major causes of AIS and its recurrences ${ }^{12,13,21}$ as is demonstrated in this study. In the two congenital heart disease cases, AIS was associated to the post operative cardiac condition; Delsing et al. described that all the cases of AIS in cardiac disease occurred after secondary cardiac surgery, and embolism which in its turn is the most common source of AIS in childhood ${ }^{22}$. Some kind of structural cardiac alteration was detected in $17.4 \%$ of the patients during the present study thus agreeing with Giroud et al. who described $19 \%$ of the alterations as mitral prolapse, ventricular septal defect, valve disease, and thromboembolism after operation ${ }^{17}$. Patent foramen ovale, although only a small cardiac defect, is held to be an important risk factor in AIS in children and adults ${ }^{1}$ and was the most frequent echocardiographic finding in our study.

About $20 \%$ of the sample did not present any type of alteration that could be associated with AIS in the present research. Similar rates were described ${ }^{1,17}$ and it was possible to detect associated or causal factors in our patients. However other diagnosis how methylenetetrahydrofolate reductase deficiency, for example, which are rare cause of AIS 
was not investigated in present study. AIS in children occurs predominately in the anterior circulation and the middle cerebral artery is the vessel most affected $8,9,14,18,22-24$ as is confirmed in this study. Cerebral AIS occurred in an adolescent who had osteosarcoma and patent foramen ovale; prior studies showed predominance of the male sex and the presence of patent oval forame in the cases of cerebellar strokes ${ }^{25}$.

Several infectious agents cause AIS in children 26 and are considered risk factors with frequency variations between $6-17 \%^{1,7}$. This present research detected $31 \%$ of acute infections associated to strokes. Recent studies have not had as an objective the direct evaluation of the presence of infection in AIS, perhaps attributing to associated conditions such as dehydration and hypertension the cause of the event. Abnormalities in the natural inhibitors of coagulation, congenital or acquired, have been a current research theme and are associated to cerebral vascular disease in infancy, and its contribution to the pathology is of extreme importance in the determination of the potential risk of recurrence, the specific therapeutic and family screening $6,23,27$. In a study of AIS and of the sinovenous thrombosis, $33 \%$ of the children presented reactant anticardiolipin antibodies, $13 \%$ alteration of the antithrombin $12 \%$ of the $S$ protein, $7 \%$ of the C protein and $9 \%$ showed resistance to activated C protein6. It is possible that the differences with our study are due to different methods. Bonduel et al. verified that $30 \%$ of AIS patients presented prothrombotic disorders, but this occurred in about $50 \%$ in our study ${ }^{7}$. This fact may be due to the great number of associated infections, principally sepsis, because the acquired deficiencies of the proteins of coagulation and thrombosis of the central nervous system, are associated with infections ${ }^{6,28}$, and it could also be a consequence of the inclusion of newborn in the research, because the prevalence of prothrombotic risk factors is high in this age $e^{9,15}$. The presence of more than one altered coagulation protein in one patient only probably indicates that the deficiency is acquired ${ }^{6}$ and multiple alterations are common in cases of AIS as compared to the controls ${ }^{15}$ and this occurred in five of our patients.

Neurological impairments were the most prevalent types of evolution in our study, which in this agrees with other studies ${ }^{8,14,22,25}$. Epilepsy, however, had a high prevalence when compared to the studies of Moura-Ribeiro et al. where the rate was $9.5 \%$ for children with cerebrovascular disease in general, which could suggest that AIS causes more epileptic alterations than haemorragic ${ }^{25}$. Almost half the studied population presented more than one probably risk factor for AIS and there is an association between these alterations and the number of after-effects. In the same way, Lanthier et al. ${ }^{5}$ concluded in their study that multiple risk factors are present in AIS and may be associated with a worse prognostic. The alterations related to the lipidic profile occurred in levels a little high in the present study, and this may be, in accordance with Ganesan et al. ${ }^{12}$ related to other factors which would justify further investigation

In the majority of studies the medication utilised is not analysed and this could be because of the lack of research on the subject ${ }^{1,29}$. However, the importance of the therapeutic conduct before a child with AIS should not be denied and the report of the clinical and therapeutic experience may help in the individual handling of each patient. Anticonvulsion drugs were the medication most often prescribed in our study (as epilepsy was a very frequent condition) followed by aspirin which is widely used in the profilaxy of AIS even without a controlled study ${ }^{29}$.One patient used an anticoagulant because of a deficiency of the $S$ protein, another who had Down's syndrome, was tetraparetic and had a deficiency of the $C$ protein, was not given an anticoagulant after the risk-benefit was evaluated. Many cases are still in therapeutic evaluation. The mortality in the present study was low when compared to other studies where rates of 11$16 \%$ were experienced ${ }^{5,14}$. In conclusion, the plurality of associated factors present in AIS in children and adolescents indicates that, very often, the event does not proceed from a single cause but is the result of the interaction of these alterations. The present research suggests the need for an extensive investigation, concentrated particularly on the prothrombotic disorders in order to better define the treatment and investigate the risk of recurrence which, for now, remain obscure.

\section{REFERENCES}

1. deVeber G. Cerebrovascular disease in children. In Swaiman K, Ashwal S, (eds). Neurology principles and practive, 3.Ed. St Louis: Mosby, 1999.

2. Lynch JK, Hirtz DG, deVeber G, Nelson KB. AVC na idade perinatal e na infância: relatório do National Institute of Neurological Disorders and Stroke. Pediatrics (ed. bras.) 2002;6:177-184.

3. Rotta NT, Silva AR, Silva FLF, et al. Cerebrovascular disease in pediatric patients. Arq Neuropsiquiatr 2002;60:959-963.

4. Montenegro MA, Guerreiro MM, Scotoni AE, Tresoldi AT, MouraRibeiro MVL. Doença cerebrovascular na infância: I. Manifestações epilépticas. Arq Neuropsiquiatr 1999;57:587-593.

5. Lanthier S, Carmant L, David M, Larbrisseau A, deVeber G. Stroke in children: the coexistence of multiple risk factors predicts poor outcome. Neurology 2000;54:371-378. 
6. deVeber G, Monagle P, Chan A, et al. Prothrombotic disorders in infants and children with cerebral thromboembolism. Arch Neurol 1998;55:1539-1543.

7. Bonduel M, Sciuccati G, Hepner M, Torres AF, Pieroni G, Frontroth JP. Prethrombotic disorders in children with arterial ischemic stroke and sinovenous thrombosis. Arch Neurol 1999;56:967-971.

8. Golomb MR, MacGregor DL, Domi T, et al. Presumed pre- or perinatal arterial ischemic stroke: risk factors and outcomes. Ann Neurol 2001;50:163-168.

9. Günther G, Junker R, Sträter R, et al. Symptomatic ischemic stroke in full-term neonates. Role of acquired and genetic prothrombotic risk factors. Stroke 2000;31:2437-2441.

10. Mercuri E, Cowan F, Gupte G, et al. Prothrombotic disorders and abnormal neurodevelopmental outcome in infants with neonatal cerebral infarction. Pediatrics 2001;107:1400-1404.

11. deVeber G. Stroke and the child's brain: an overview of epidemiology, syndromes and risk factors. Neurology 2002;15:133-138.

12. Ganesan V, Prengler M, McShane MA, Wade AM, Kirkham FJ. Investigation of risk factors in children with arterial ischemic stroke. Ann Neurol 2003;53:167-173.

13. Ganesan V, Hogan A, Shack N, Gordon A, Isaacs E, Kirkham FJ. Outcome after ischaemic stroke in childhood. Dev Med Child Neurol 2000;42:455-461.

14. De Schryver EL, Kappelle LJ, Jennekens-Schinkel A, Boudewyn Peters AC. Prognosis of ischemic stroke in childhood: a long-term follow-up study. Dev Med Child Neurol 2000;42:313-318.

15. Kenet G, Sadetzki S, Murad H, et al. Factor V leiden and antiphospholipid antibodies are significant risk factors for ischemic stroke in children. Stroke 2000;31:1283-1288.

16. Williams LS, Garg BP, Cohen M, Fleck JD, Biller J. Subtypes of ischemic stroke in children and young adults. Neurology 1997;49:1541-1545.

17. Giroud M, Lemesle M, Madinier G, Manceau E, Osseby GV, Dumas R. Stroke in children under 16 years of age. Clinical and etiological difference with adults. Acta Neurol Scand 1997;96:401-406.
18. Ganesan V, Chong WK, Cox TC, Chawda SJ, Prengler M, Kirkham FJ. Posterior circulation stroke in childhood: risk factors and recurrence. Neurology 2002;59:1552-1556.

19. Scher MS, Wiznitzer M, Bangert BA. Cerebral infarctions in the fetus and neonate: maternal-placental-fetal considerations. Clin Perinatol 2002;29:693-724.

20. Visudtibhan A, Visudhiphan P, Chiemchanya S. Stroke and seizures as the presenting signs of Pediatric HIV infection. Pediatr Neurol 1999;20:53-56.

21. Earley CJ, Kittner SJ, Feeser BR, et al. Stroke in children and sickle-cell disease. Baltimore-Washington Cooperative Young Stroke Study. Neurology 1998;51:169-176.

22. Delsing BJP, Catsman-Berrevoets CE, Appel IM. Early prognostic indicators of outcome in ischemic childhood stroke. Pediatr Neurol 2001;24:283-289.

23. Oláh L, Misz M, Kappelmayer J, et al. Natural coagulation inhibitor proteins in young patients with cerebral ischemia. Cerebrovasc Dis 2001; 12:291-297.

24. Moura-Ribeiro MV, Ferreira LS, Montenegro MA, et al. Doença cerebrovascular na infancia: II Aspectos clinicos em 42 casos. Arq Neuropsiquiatr 1999;57:594-598.

25. Barinagarrementeria F, Amaya LE, Cantú C. Causes and mechanisms of cerebellar infarction in young patients. Stroke 1997;28:2400-2404.

26. Takeoka M, Takahashi T. Infectious and inflammatory disorders of the circulatory system and stroke in childhood. Neurology 2002;15:159-164.

27. Nowak-Göttl U, Sträter R, Heinecke A, et al. Lipoprotein (a) and genetic polymorphisms of clotting factor $\mathrm{V}$, prothrombin, and methylenetetrahydrofolate reductase are risk factors of spontaneous ischemic stroke in childhood. Blood 1999;94:3678-3682.

28. Ganesan V, McShane MA, Liesner R, Cookson J, Hann I, Kirkham FJ. Inherited prothrombotic states and ischaemic stroke in childhood. J Neurol Neurosurg Psychiatry 1998;65:508-511.

29. Roach ES. Stroke in children. Curr Treat Options Neurol 2000;2:295-303. 